come of the hard conditions in which they grew, these traditions have been appreciated by the rest of the world. In studying stories of the origin of death one sees how the essential theme varies widely according to environment and experience. In certain instances Miss Fleming traced the adaptation to particular environments of a central theme. Lastly she showed how tradition grew and lingered around early trade routes.

The morning of September 13 closed with a paper by Mr. H. M. Spink on the distribution of commercial timber on the Pacific Coast of North America. In the afternoon Mr. A. W. Grabham lectured on his recent experiences in a journey from Lake Tana to Roseires, paying spècial regard to the water supply. The work of Section. $E$ included visits to Leith docks and the cartographical works of Messrs. J. Bartholomew and Co., and Messrs. W. and A. K. Johnston.

\section{An Automatic Recorder of Smoke Pollution.}

$\mathrm{I}$ an article on "London Air" in the Times of 1 August 23 Sir Napier. Shaw directed attention to the clear atmosphere which was such a noticeable feature in all industrial centres during the recent coal strike. The article in question is, however, chiefly interesting for its description of an ingenious self-recording contrivance invented by Dr. J. S. Owens for the Atmospheric Pollution Committee of the Meteorological Office, which registers hourly the amount of solid atmospheric impurities. A fixed volume of air is aspirated through a small disc of filter-paper, and from the depth of shade the amount of deposit is estimated by comparison with discs of standard shades. In London the notably dirty period is from 9 a.m. to 5 p.m., i.e. the business hours of the day. The greatest impurity. is, of course, in winter, that of a May day being about one-quarter that of a November day. The day impurity in May is of the same order as the night impurity in November. The instrument should prove useful in detecting any noticeable improvement or otherwise in the amount of solid impurities in different towns. Although Sir Napier Shaw states that these measurements of the Committee " are noteworthy as the first series of systematic observations of the pollution of the air of London and other centres of population," he has apparently overlooked the fact that a complete series of records was made in Leeds some years previously, in the course of which it was clearly established not only that the domestic fireplace is responsible for much the larger proportion of the soot emitted from burning coal, but also, more important still, that this domestic soot is much more highly contaminated with tar than that from factory chimneys. In his reference to possible means of smoke prevention from domestic fireplaces, Sir Napier Shaw makes no reference to the carefully considered report which was published in the autumn of last year by the Committee on Smoke Abatement appointed by the Ministry of Health. It was there pointed out that the ordinary open kitchen range was wasteful and inefficient, and the Committee strongly insisted on the advantage of gas-cookers where gas was available. Low-temperature coke was also advocated whenever the right sort of material could be placed upon the market--a desideratum not yet attained. But there are numerous forms of improved ranges in which coke and anthracite can be burned much more economically than in the old open range, and, of course, without the emission of smoke. It now remains for the Ministry of Health to bring pressure to bea- on those engaged upon Government building schemes to adopt these recommendations. It has a unique opportunity for setting an example in atmospheric purification.

\section{University and Educational Intelligence.}

Berrast.-Dr. J. K. Charlesworth has been appointed professor of geology in the Queen's University. Until the present session the head of the department of geology was a lecturer, but, owing to the importance of the subject, the Senate has raised the lectureship to a professorship.

BIRMingham.-The University has now been in existence for twenty-one years, and in commemoration of the event the Council and Senate have invited a large number of friends of the University to a conversazione on October 7, at which the Edgbaston buildings will be open to inspection.

London.-Mr. A. E. Webb has been appointed senior assistant in the department of civil and mechanical engineering of University College. Mr. C. D. Burns has been appointed lecturer in philosophy at Birkbeck College.

In connection with the department of philosophy of King's College a course of ten public lectures will be given by Prof. H. Wildon Carr on "The Modern Scientific Revolution and its Meaning for Philosophy " on Tuesdays at 5.30 , beginning on October $\mathrm{r}$. In connection with the faculty of psychology a similar number of lectures on "Psychology and Psychotherapy " will be given by Dr. W. Brown on Tuesdays at 5.30 beginning on October 18 .

St. Andrews.-Dr. W. J. Tulloch, lecturer in bacteriology in the University, has been appointed to be the first professor of the chair of bacteriology, established and approved by his Majesty in Council on June 27 last.

The Salters' Institute of Industrial Chemistry has awarded fellowships for post-graduate study in the laboratories of the institute to Messrs. J. A. Gentle, F. Raymond Jones, S. J. Saint, and F. W. Turner. Scholarships have been awarded to Messrs. B. G. Banks and L. G. Laws.

Post-Graduate research scholarships in naval architecture of $250 l$. a year each have been awarded by the Institution of Naval Architects to Mr. H. W. Nicholls, of the Royal Naval College, Greenwich, who will carry out research on the vibration of ships, and Mr. W. R. Andrew, of Liverpool University, who will investigate the behaviour of ships at sea during a longdistance voyage, and report on shipbuilding and conditions abroad.

Some bequests of noteworthy importance are made in the will of Mrs. L. A. Stuart, widow of Prof. James Stuart. Cambridge University Local Lecture Syndicate will receive a sum of $5000 l$. for a James Stuart endowment in memory of Prof. Stuart's work in founding the University Extension Lectures. In addition, Trinity College, Cambridge, is to receive $2000 l$. which it is suggested should be applied to the establishment of Stuart scholarships or studentships, and a similar sum is bequeathed to Newnham College, Cambridge.

ON Tuesday, October II, a dinner in honour of Prof. J. C. Philip will be held in the Imperial College Union, Prince Consort Road, South Kensington, at 7 for $7 \cdot 30$ p.m., when Sir William A. Tilden will present to him an illuminated address and gifts from his colleagues and students to express deep appreciation of Prof. Philip's active interest in every movement for the advancement of the Royal College of Science during his service, now twenty-one years, on the chemical staff of the college. The chair will be taken by Sir Richard Gregory, president of the Royal College of Science Association. NO. 2709 , VOL. IO8] 